\title{
Efek Terapi Oksigen Hiperbarik (TOHB) pada Penyembuhan Ulkus Kaki DM Tipe 2 Berdasarkan Skor PEDIS
}

\author{
${ }^{1}$ Ekanova R. N. Sumarauw, ${ }^{2}$ Mendy J. Hatibie, ${ }^{3}$ Djony E. Tjandra, ${ }^{4}$ Fredrik G. Langi
}

\author{
${ }^{1}$ PPDS Ilmu Bedah Fakultas Kedokteran Universitas Sam Ratulangi Manado. \\ ${ }^{2}$ Divisi Bedah Plastik Bagian Ilmu Bedah Universitas Sam Ratulangi/RSUP Prof. Dr. R.D. \\ Kandou Manado. \\ ${ }^{3}$ Divisi Bedah Vaskular Bagian Ilmu Bedah Universitas Sam Ratulangi/RSUP Prof. Dr. R. \\ D. Kandou Manado. \\ ${ }^{4}$ Fakultas Kesehatan Masyarakat, Universitas Sam Ratulangi Manado \\ Email: ekanova.s@gmail.com
}

\begin{abstract}
Diabetic foot ulcer (DFU) is still a health problem related to the extent amount of time in wound healing process hence increasing the treatment cost. Given any methods that are not satisfying, encourage the search of other methods that would increase the wound healing rate, in which hyperbaric oxygen therapy (HBOT) is amongst them. The DFU patient that receives HBOT shows a significant increase in angiogenesis process markedly by faster epithelialization and granulation process. This study was aimed to prove that HBOT could accelerate the wound healing process among DFU patients measured by wound size and depth of PEDIS score. This was a randomized controlled trial study, conducted at Surgery Department of Prof. Dr. R. D. Kandou General Hospital from September 2018 to March 2019. There were 20 DFU patients divided into two groups, each of 10 patients. The control group received a holistic treatment, meanwhile the HBOT group received a holistic treatment added with the inclusion of HBOT. PEDIS score assessment of DFU in HBOT group was measured before and after the third HBOT session, meanwhile the control group was measured on the first and the third day. The results showed that the difference in PEDIS score value was markedly found in HBOT group compared to the control group ( 2 vs. 0 , $P=0.001)$. Conclusion: HBOT could enhance the wound healing process in DFU patients based on the declined PEDIS score.
\end{abstract}

Keywords: HBOT, PEDIS score, diabetic foot ulcer

\begin{abstract}
Abstrak: Ulkus kaki diabetik (UKD) masih merupakan masalah kesehatan terkait proses penyembuhan lama sehingga biaya pengobatan meningkat. Belum adanya metode penanganan yang memuaskan, mendorong pencarian metode percepatan penyembuhan luka, salah satunya ialah terapi oksigen hiperbarik (TOHB). Penderita UKD yang menjalani tambahan TOHB diketahui mengalami peningkatan proses angiogenesis yang menghasilkan proses epitelialisasi dan granulasi yang lebih cepat. Tujuan penelitian ialah untuk membuktikan bahwa TOHB dapat mempercepat proses penyembuhan UKD, dinilai berdasarkan ukuran dan kedalaman luka melalui skor PEDIS. Penelitian ini menggunakan randomized controlled trial dan dilaksanakan di Bagian Bedah RSUP Prof. Dr. R.D. Kandou Manado sejak September 2018 sampai dengan Maret 2019. Subyek penelitian sebanyak 20 penderita UKD, dibagi dalam dua kelompok, masing-masing 10 penderita. Kelompok kontrol menjalani penanganan holistik UKD, sedangkan kelompok TOHB menjalani penanganan holistik UKD dengan TOHB. Penilaian skor PEDIS terhadap UKD pada kelompok TOHB dilakukan sebelum dan sesudah TOHB sesi ke-3, sedangkan pada kelompok kontrol dilakukan penilaian pada hari ke-1 dan hari ke-3 sesudahnya. Hasil penelitian mendapatkan bahwa perubahan skor PEDIS yang terjadi antara kedua pengukuran terlihat lebih besar pada kelompok TOHB dibandingkan kelompok kontrol ( 2 vs $0, P=0,001)$. Simpulan. TOHB mempercepat proses penyembuhan UKD dinilai dari penurunan skor PEDIS.
\end{abstract}

Kata kunci: TOHB, skor PEDIS, ulkus kaki diabetik 
Ulkus kaki diabetes melitus tipe 2 (UKD) masih merupakan salah satu masalah besar bagi kesehatan dan sosial terkait biaya pengobatan pada penyandang diabetes melitus (DM). Diabetes melitus termasuk dalam 10 penyakit teratas berdasarkan laporan surveilans terpadu puskesmas (STP) berbasis puskesmas di provinsi Sulawesi Utara tahun 2016 dengan jumlah kasus sebesar 5.055 kasus dengan estimasi jumlah penduduk provinsi Sulawesi Utara diatas usia 15 tahun sebanyak 1.813.975 orang. ${ }^{1}$

Sampai saat ini belum terdapat metode penanganan yang memuaskan., ${ }^{2,3}$ Hal ini mendorong pencarian metode yang dapat merangsang percepatan penyembuhan luka, salah satu diantaranya ialah dengan menggunakan terapi oksigen hiperbarik (TOHB). ${ }^{4}$ Terapi oksigen hiperbarik adalah metode terapi dengan menggunakan $100 \%$ oksigen pada tekanan yang lebih tinggi dari tekanan atmosfer permukaan air laut, yaitu pada tekanan 2-3 atmosphere absolute (ATA) di dalam ruangan hiperbarik. ${ }^{3-5}$

Penderita UKD yang menjalani tambahan TOHB diketahui mengalami peningkatan proses angiogenesis yang menghasilkan proses epitelialisasi dan granulasi menjadi lebih cepat. ${ }^{6}$ Hal ini mendorong peneliti untuk mendalami lebih lanjut mengenai peran TOHB terhadap penyembuhan UKD; selain itu juga dikarenakan TOHB belum menjadi terapi standar bagi penderita UKD. Secara khusus, penelitian ini bertujuan untuk membuktikan bahwa TOHB dapat memperkecil ukuran dan kedalaman luka melalui skor PEDIS.

\section{METODE PENELITIAN}

Penelitian ini menggunalan metode randomized controlled trial (RCT) yang dilaksanakan sejak bulan September 2018 s/d Maret 2019 di Bagian Bedah RSUP Prof. Dr. R. D. Kandou Manado. Penelitian ini telah mendapatkan persetujuan dari Komisi Etik Penelitian Kesehatan RSUP Prof. Dr. R. D. Kandou Manado.

Pasien bersedia untuk berpartisipasi dalam penelitian dengan menandatangani surat persetujuan (informed consent) setelah mendapat penjelasan tentang keuntungan dan risiko yang dapat terjadi selama penelitian. Kriteria inklusi ialah penyandang DM tipe 2 (DMT2) dengan komplikasi UKD dan sedang atau telah mendapatkan tatalaksana UKD, nilai Ankle Brachial Index $\geq 0,9, \mathrm{HbA} 1 \mathrm{c} \leq 8 \%$, albumin serum >3,5 $\mathrm{g} \%$, dan nilai $\mathrm{Hb} \geq 8 \mathrm{~g} \%$, sedangkan kriteria eksklusi ialah penyandang DM tipe 1 (DMT1) dan DM gestasional, ulkus tanpa riwayat penyakit DMT2, ulkus akibat trauma mayor, keganasan, osteomielitis, koagulopati, penyakit vaskular perifer lainnya, dan kontraidikasi terhadap TOHB.

Penilaian skor PEDIS terhadap UKD pada kelompok TOHB dilakukan sebelum TOHB dan sesudah TOHB sesi ke-3, sedangkan pada kelompok kontrol dilakukan penilaian pada hari ke-1 dan hari ke-3 sesudahnya. Terapi oksigen hiperbarik menggunakan inhalasi oksigen berkonsentrasi $100 \%$ pada tekanan 2,4 ATA dalam ruangan oksigen hiperbarik selama 60 menit yang dibagi dalam dua durasi masing-masing 30 menit dengan jeda 10 menit, dilakukan setiap hari selama 3 hari.

Analisis statistik dilakukan melalui software statistik $\mathrm{R}$ versi 3.5.2 (The $R$ Foundation). Variabel numerik disajikan sebagai nilai mean dan standard deviation, atau median dan jarak antar kuartil (interquartile range, IQR) bila uji Shapiro Wilk menunjukkan bahwa data terdistribusi tidak normal. Variabel kategorial ditampilkan dalam jumlah total $\mathrm{n}$ dan proporsi. Perbedaan karakteristik pasien menurut kelompok perlakuan (TOHB vs kontrol) diuji dengan tes $t$ atau Mann-Whitney $\mathrm{U}$ bagi variabel numerik, dan uji chi-square untuk variabel kategorial. Model regresi linear digunakan untuk menguantifikasi efek TOHB terhadap masing-masing outcome, baik sebelum (analisis regresi univariat) maupun setelah mengontrol variabel lainnya dalam model (analisis multivariat). Di luar kelompok terapi sebagai faktor utama, variabel independen lain dalam model multivariabel dipilih via forward selection. Hasil pemodelan regresi dilaporkan sebagai nilai estimat $(\beta)$, batas 
bawah dan atas dari interval kepercayaan (confidence interval, CI) 95\%, dan nilai $P$.

\section{HASIL PENELITIAN}

Sebanyak 20 penderita ulkus kaki diabetes melitus tipe 2 (UKD) berpartisipasi dalam penelitian ini dan dibagi dalam kelompok TOHB dan kelompok kontrol, masing-masing sebanyak 10 orang. Tabel 1 memperlihatkan karakteristik pasien yang mendapat TOHB dan pasien kontrol.

Tabel 2 menampilkan penilaian proses penyembuhan luka yakni skor PEDIS, diperoleh dalam dua kali pengukuran selama penelitian.

Skor PEDIS umumnya turun pada pengukuran ke-2, yakni sesudah TOHB sesi ke-3, dengan median penurunan sekitar satu poin. Tidak terlihat perbedaan bermakna antara skor PEDIS kedua kelompok terapi baik pada baseline maupun pengukuran setelah TOHB sesi ke-3. Namun demikian, perubahan yang terjadi antara kedua pengukuran terlihat lebih besar pada kelompok TOHB dibandingkan dengan kontrol (2 vs $0, \quad P=0,001)$. Perubahan pada skor PEDIS dari kelompok TOHB nampak lebih jelas daripada kelompok kontrol pada baseline dan sesudah TOHB sesi ke-3 (Gambar 1). Pemberian TOHB secara kasar nampaknya mampu memperlihatkan Terapi oksigen hiperbarik juga menurunkan skor PEDIS sekitar 1 poin setelah TOHB sesi ketiga pada model univariabel. Efek tersebut kemudian menjadi signifikan setelah skor PEDIS pada baseline, ukuran luka pada baseline, dan onset luka dikontrol dalam model multivariabel $(P=0,001)$.

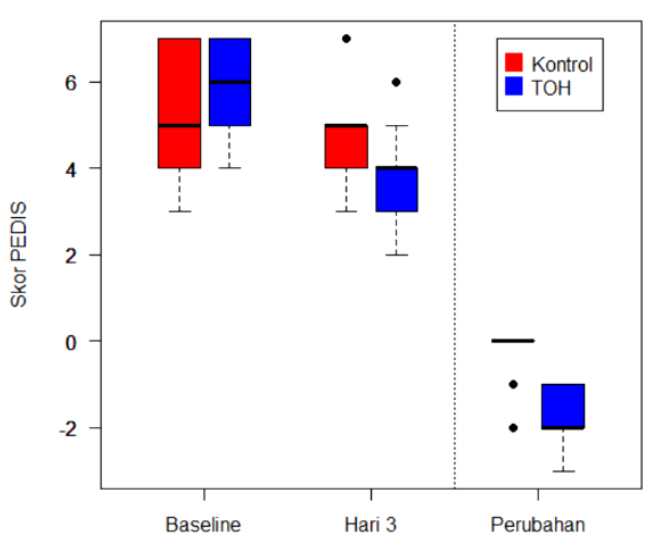

Gambar 1. Perubahan skor PEDIS pasien kelompok TOHB vs kelompok kontrol

Tabel 1. Karakteristik pasien diabetes melitus tipe 2 dalam penelitian

\begin{tabular}{|c|c|c|c|c|c|c|c|}
\hline \multirow{3}{*}{ Variabel } & \multicolumn{6}{|c|}{ Kelompok terapi } & \multirow{3}{*}{$p^{\mathbf{a}}$} \\
\hline & \multicolumn{2}{|c|}{ Total $(\mathrm{N}=20)$} & \multicolumn{2}{|c|}{ Oksigen hiperbarik $(\mathrm{n}=10)$} & \multicolumn{2}{|c|}{ Kontrol $(\mathrm{n}=10)$} & \\
\hline & $\mu \pm \mathrm{SD}$ & Med (Q1;Q3) & $\mu \pm \mathrm{SD}$ & Med (Q1;Q3) & $\mu \pm \mathrm{SD}$ & Med (Q1;Q3) & \\
\hline \multicolumn{8}{|l|}{ Kelamin, n (\%) } \\
\hline Perempuan & $6(30)$ & * & $2(20)$ & * & $4(40)$ & $*$ & 0,628 \\
\hline Laki-laki & $14(70)$ & $*$ & $8(80)$ & $*$ & $6(60)$ & $*$ & \\
\hline Usia (tahun) & $56,7 \pm 9,5$ & $*$ & $54,8 \pm 9,7$ & $*$ & $58,6 \pm 9,4$ & $*$ & 0,385 \\
\hline Berat (kg) & $*$ & $59,0(55,8 ; 64,2)$ & $*$ & $57,5(56,2 ; 63,8)$ & $*$ & $60,0(55,2 ; 65,2)$ & 0,820 \\
\hline Tinggi $(\mathrm{cm})$ & $163,8 \pm 7,8$ & $*$ & $163,2 \pm 7,8$ & $*$ & $164,5 \pm 8,1$ & $*$ & 0,708 \\
\hline IMT (kg/m2) & $*$ & $22,5(20,7 ; 23,5)$ & $*$ & $22,5(21,4 ; 23,2)$ & $*$ & $21,8(20,5 ; 23,9)$ & 0,791 \\
\hline Onset DM (tahun) & $*$ & $10,0(5,0 ; 20,0)$ & $*$ & $16,5(6,2 ; 20,0)$ & $*$ & $7,5(5,0 ; 10,0)$ & 0,088 \\
\hline Onset Luka (minggu) & $*$ & $8,0(4,0) ; 30,0)$ & $*$ & $30,0(9,0) ; 48,0)$ & $*$ & $4,0(4,0) ; 8,0)$ & 0,023 \\
\hline Merokok, n (\%) & $4(20)$ & $*$ & $3(30)$ & $*$ & $1(10)$ & $*$ & 0,582 \\
\hline Hemoglobin (g/dL) & $9,9 \pm 1,6$ & $*$ & $9,8 \pm 1,9$ & $*$ & $10,0 \pm 1,4$ & $*$ & 0,774 \\
\hline Eritrosit $(106=\mathrm{mL})$ & $3,6 \pm 0,6$ & $*$ & $3,4 \pm 0,7$ & $*$ & $3,8 \pm 0,5$ & $*$ & 0,228 \\
\hline Trombosit $(103=\mathrm{mL})$ & $394,0 \pm 114,3$ & $*$ & $424,0 \pm 137,2$ & $*$ & $364,0 \pm 820,3$ & $*$ & 0,251 \\
\hline HbA1c $(\%)$ & $6,4 \pm 0,9$ & $*$ & $6,5 \pm 0,9$ & $*$ & $6,3 \pm 0,8$ & $*$ & 0,640 \\
\hline Albumin & $*$ & $3,5(3,5 ; 3,6)$ & $*$ & $3,5(3,5 ; 3,6)$ & $*$ & $3,6(3,5 ; 3,6)$ & 0,730 \\
\hline $\mathrm{ABI}$ & $*$ & $0,9(0,9 ; 1,0)$ & * & $1,0(0,9 ; 1,0)$ & $*$ & $0,9(0,9 ; 1,0)$ & 0,671 \\
\hline
\end{tabular}

Keterangan: SD standar deviasi, Med median, Q1 kuartil I, Q3 kuartil III, IMT indeks massa tubuh, DM diabetes melitus, ABI ankle brachial index. ${ }^{\text {a }}$ Uji $t$ atau Mann-Whitney $U$ pada variabel numerik, uji $\chi^{2}$ pada variabel kategorial 
Tabel 2. Perubahan skor PEDIS

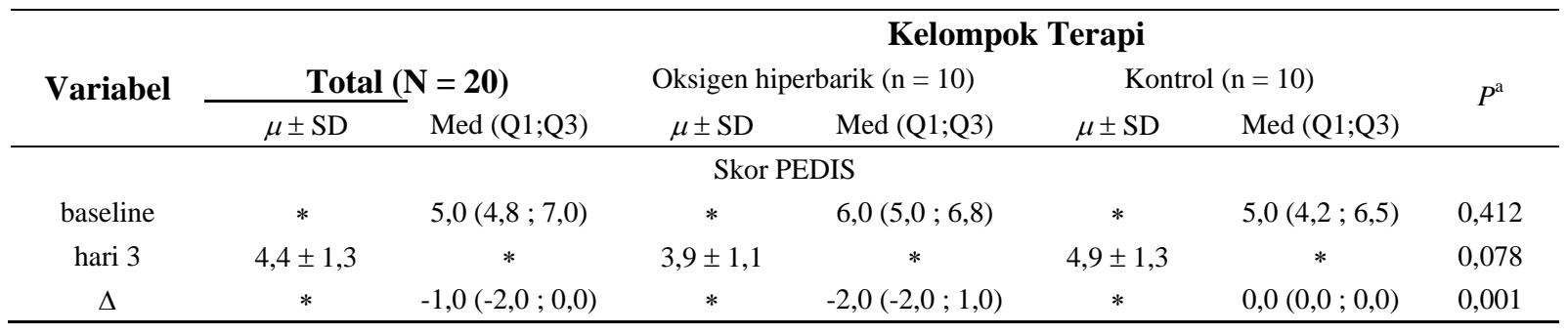

Keterangan: SD = standar deviasi, Med = median, Q1 = kuartil I, Q3 = kuartil III, IMT = indeks massa tubuh, $\mathrm{DM}=$ diabetes mellitus. a Uji t atau Mann-Whitney U, menurut normalitas distribusi.

Tabel 3. Model regresi linear efek TOHB terhadap VEGF dan skor PEDIS

\begin{tabular}{ccccc}
\hline \multirow{2}{*}{ Outcome } & \multicolumn{3}{c}{ Terapi Oksigen Hiperbarik vs Kontrol } \\
& \multicolumn{2}{c}{ Model Univariabel } & \multicolumn{2}{c}{ Model Multivariabel $^{\mathrm{a}}$} \\
& $\beta(95 \% \mathrm{CI})$ & $P$ & $\beta(95 \% \mathrm{CI})$ & $P$ \\
\hline Skor PEDIS hari ke-3 & $-1,00(-2,12 ; 0,12)$ & 0,078 & $-1,24(-1,83 ;-0,66)$ & 0,001 \\
\hline
\end{tabular}

Keterangan: $\mathrm{CI}=$ confidence interval, ${ }^{\mathrm{a}}=$ Variabel selain terapi (TOHB vs kontrol) yang dikontrol untuk setiap outcome: ukuran luka baseline; dan Skor PEDIS hari ke-3 skor PEDIS baseline, ukuran luka baseline, onset luka

\section{BAHASAN}

Pada penelitian ini didapatkan bahwa intervensi dengan TOHB dapat mempercepat penyembuhan UKD, yang dinilai dengan penurunan skor PEDIS. Pada subyek dalam kelompok TOHB dilakukan pengukuran nilai skor PEDIS setelah TOHB sesi ke-3 yang menunjukkan penurunan secara bermakna dibandingkan dengan kelompok kontrol. Hal ini menunjukkan bahwa TOHB dapat mempercepat angiogenesis. Hasil penelitian ini sesuai dengan laporan penelitian lainnya. Ueno et $\mathrm{al}^{7}$ meneliti 29 penderita dengan luka kronis, 13 diantaranya meyandang penyakit DM. Penderita diberikan TOHB selama 6 minggu. Walaupun terdapat 4 penderita DM dengan penyembuhan luka yang buruk, namun jelas terindikasi bahwa TOHB memiliki peran yang bermakna dalam mempercepat penyembuhan luka. Hongmei et al melaporkan penelitian terhadap 44 pasien UKD dengan TOHB sebagai terapi tambahan dan menunjukkan tingkat efektifitas sebesar $77,3 \%$ yang secara bermakna lebih baik dibandingkan $54,5 \%$ dengan penanganan konvesional. ${ }^{8}$ Pada penelitian yang dilakukan $\mathrm{Li}$ et $\mathrm{al}^{9}$ didapatkan perbedaan antar kelompok yang menunjukkan luas luka pada kelompok observasi yang menerima TOHB secara bermakna lebih rendah dibandingkan kelompok kontrol pada minggu ke-2, ke-3, ke-4, dan ke-5.

Dasar terapeutik pada TOHB ialah peningkatan kuantitas oksigen terlarut yang diangkut oleh darah yang mengakibatkan peningkatan bermakna dari konsentrasi oksigen dalam jaringan tubuh. Konsentrasi oksigen yang tinggi dapat meningkatkan produksi ROS; namun disisi lain TOHB menginduksi lingkungan antioksidan dalam plasma dengan meningkatkan aktivitas katalase plasma. Peningkatan kadar ROS dapat memediasi ekspresi dari molekulmolekul kunci pada inflamasi, resolusi dan perbaikan luka. Dengan demikian, peningkatan ini dapat dianggap sebagai mekanisme utama kerja TOHB dalam penyembuhan luka. $^{10}$

TOHB menginduksi produksi ROS yang dapat bertindak sebagai sinyal yang memediasi respons fisiologik dalam mitokondria. TOHB mempertahankan integritas mitokondria melalui pemeliharaan potensi membran mitokondria dan pengurangan jalur apoptosis mitokondria. Sesi berulang TOHB dapat menginduksi adaptasi pada 
mesin oksidatif neutrofil untuk mengurangi respons terhadap stimulus, mengurangi respon inflamasi, dan meningkatkan proses pemulihan di jaringan yang rusak. Dalam hal ini, sesi TOHB memromosikan respon anti-inflamasi yang mirip dengan resolusi respon inflamasi oleh mediator lipid termasuk resolvins dan beberapa jenis sitokin. Resolvins memberikan efek antiinflamasi yang kuat dengan menekan infiltrasi neutrofil berlebihan ke dalam jaringan dan mengurangi produksi mediator proinflamasi. Penyandang DM akan mengalami pergeseran penyembuhan luka yang diakibatkan oleh gangguan diabetik dari fase resolusi penyembuhan luka. ${ }^{10}$

Peningkatan pasokan oksigen dapat memicu metabolisme sel lokal dan mempercepat pemulihan fungsi sel, sehingga terjadi peningkatan pembelahan fibroblas dan mempercepat perbaikan mikrovaskular dan angiogeneis kapiler. Hal ini membantu untuk memperbaiki mikrosirkulasi dan mempercepat penyembuhan luka. ${ }^{10}$

Pada penelitian ini, klasifikasi PEDIS digunakan pada evaluasi UKD. Sistem klasifikasi PEDIS mendefinisikan UKD sesuai dengan kriteria yang lebih ketat berdasarkan teknik obyektif dan parameter yang lebih komprehensif terkait penyembuhan ulkus. ${ }^{11}$

Ulkus kaki diabetik diklasifikasikan berdasarkan lima kategori: perfusi, luas luka, kedalaman luka, infeksi, dan sensasi berdasarkan sistem klasifikasi PEDIS. Perfusi ditentukan oleh kombinasi pemeriksaan fisik dan studi vaskular noninvasif. Tanda-tanda klinis didasarkan pada tidak adanya pulsasi arteri dorsalis pedis atau arteri tibialis posterior dari kaki yang terlibat. Kriteria noninvasif termasuk anklebrachial index (ABI), toe-brachial index (TBI), tekanan oksigen transkutan $\left(\mathrm{TcpO}_{2}\right)$ dan ankle/toe pressure. Mengenai luas luka diperkirakan dengan mengalikan diameter terbesar dengan diameter terbesar kedua yang diukur tegak lurus terhadap diameter pertama dan dinyatakan sebagai $\mathrm{cm}^{2}$. Untuk menentukan standar skor kategori luas luka, ulkus dialokasikan ke salah satu kelompok berikut: kulit utuh, <1 cm2, 1-3 $\mathrm{cm} 2$, atau $>3 \mathrm{~cm} 2$. Untuk kedalaman luka dievaluasi menggunakan probe nasal tumpul steril dan tes pencitraan. Diagnosis infeksi terutama didasarkan pada ada tidaknya gejala dan tanda-tanda peradangan, dan adanya sekresi, hasil tes laboratorium dan tes pencitraan. Sensasi dievaluasi dengan monofilamen 10-g dan/atau sensasi garpu tala $128 \mathrm{~Hz}$ pada satu atau lebih lokasi kaki. Lima kategori terpisah dari sistem klasifikasi PEDIS dijumlahkan, menghasil-kan kisaran skor PEDIS 0-12. Skor kategori PEDIS dapat dijumlahkan menjadi skor PEDIS agregat, dengan skor 7 atau lebih dikaitkan dengan kemungkinan kesulitan penyembuhan yang lebih besar secara bermakna. ${ }^{11}$

Pada penelitian ini digunakan skor kategori PEDIS untuk menentukan secara cepat dan akurat perkembangan penyembuhan luka pada UKD karena dianggap sebagai metode terbaik dalam menentukan perbedaan kemampuan pengambilan klinis dan memiliki kapasitas yang baik untuk memrediksi outcome dibandingkan sistem penilaian yang lain. Penelitian $\mathrm{Li}$ et $\mathrm{al}^{9}$ menunjukkan bahwa nilai ambang batas yang memaksimalkan sensitivitas dan spesifisitas untuk hasil yang merugikan (adverse outcomes) untuk skor PEDIS ialah 7. Untuk identifikasi hasil yang merugikan, skor PEDIS memiliki sensitivitas $93 \%$ dan spesifisitas $82 \%$. Nilai di atas dianggap lebih baik jika dibandingkan dengan sistem skor SINBAD dan Wagner yang masingmasing memiliki sensitivitas $90 \%$ dan $88 \%$, dan spesifisitas $73 \%$ dan $80 \%$. $^{11}$

\section{SIMPULAN}

Terapi oksigen hiperbarik (TOHB) dapat mempercepat proses penyembuhan ulkus kaki diabetik DMT2, dinilai melalui penurunan skor PEDIS. Diharapkan agar TOHB dapat menjadi standar prosedur penatalaksanaan UKD.

\section{SARAN}

Hasil penelitian ini menunjukkan bahwa TOHB memiliki efek terapi tambahan terhadap penyembuhan UKD, dan penelitian lanjutan perlu dilakukan untuk 
mengetahui mekanisme kerja TOHB secara pasti. Suatu penelitian terkontrol dengan jumlah pasien yang besar sangat diperlukan untuk melakukan analisis lanjut.

Selain itu diperlukan penelitian dengan biomarker pada proses penyembuhan UKD.

\section{DAFTAR PUSTAKA}

1. Balai Data Penelitian dan Pengembangan Kesehatan. Profil kesehatan provinsi Sulawesi Utara tahun 2016. Manado: Dinas Kesehatan Daerah Provinsi Sulawesi Utara, 2017.

2. Kessler L, Bilbault P, Ortega F, Grasso C, Passemard R, Stephan D, et al. Hyperbaric oxygenation accelerates the healing rate of nonischemic chronic diabetic foot ulcers: a prospective randomized study. Diabetes Care. 2003;26(8):2378-82.

3. Flood MS. Hyperbaric oxygen therapy for diabetic foot ulcers. JLGH. 2007; 2(4):141-5.

4. Vishwanath G, Bhutani S. Hyperbaric oxygen and wound healing. Indian $\mathbf{J}$ Plast Surg. 2012;45(2):316.

5. Sahni T, Hukku S, Jain M, Prasad A, Prasad R, Singh K. Recent advances in hyperbaric oxygen therapy. Med Update. 2004;14:632-9.

6. Hanft JR, Pollak RA, Barbul A, Gils C van, Kwon PS, Gray SM, et al. Phase I trial on the safety of topical rhVEGF on chronic neuropathic diabetic foot ulcers. J Wound Care. 2008;17(1):30-7.

7. Ueno T, Omi T, Uchida E, Yokota H, Kawana S. Evaluation of hyperbaric oxygen therapy for chronic wounds. J Nippon Med Sch. 2014;81(1):4-11.

8. Stoekenbroek RM, Santema TB, Legemate DA, Ubbink DT, Van den Brink A, Koelemay MJW. Hyperbaric oxygen for the treatment of diabetic foot ulcers: a systematic review. Eur $\mathrm{J}$ Vasc Endovasc Surg. 2014;47(6):647-55.

9. Li N, Meng XE, Guo DZ, Fan DF, Pan SY. Wound healing process and related laboratory indexes in patients with type 2 diabetes mellitus after hyperbaric oxygen intervention. Biomed Res. 2017;28(20):9005-10.

10. Sureda A, Batle JM, Martorell M, Capó X, Tejada S, Tur JA, et al. Antioxidant response of chronic wounds to hyperbaric oxygen therapy. PLOS ONE. 2016;11(9):e0163371.

11. Chuan F, Tang K, Jiang P, Zhou B, He X. Reliability and validity of the perfusion, extent, depth, infection and sensation (PEDIS) classification system and score in patients with diabetic foot ulcer. PLOS ONE. 2015;10(4): e0124739. 